\title{
Influence of migration processes in Europe on law and legal culture of information society
}

\author{
Elena Pevtsova ${ }^{1, *}$, Natali Pevtsova ${ }^{2}$, Marina Lavitskaya $^{3}$, Vladimir Redkous $^{4}$ and Evgeniia \\ Matveeva $^{5}$ \\ ${ }^{1}$ Moscow Region State University, 10A, Radio str., 105005, Moscow, Russia, \\ ${ }^{2}$ Lomonosov Moscow State University, d.1, p.52, Lenin Mountains, 119234, Moscow, Russia \\ ${ }^{3}$ Russian State University for the Humanities, 15, Chayanova str., 125047, Moscow, Russia \\ ${ }^{4}$ Academy of Management of the Ministry of Internal Affairs of Russia, 8, Zoe and Alexander \\ Kosmodemyanskikh str., 125993, Moscow, Russia \\ ${ }^{5}$ Central Russian Institute of Management, Branch of the Russian Presidential Academy of National \\ Economy and Public Administration, 5a, Victory Boulevard, 302028, Oryol, Russia
}

\begin{abstract}
The relevance of research: The relevance of the problem under study is evidenced, first, by an active scientific discourse among lawyers on the impact of migration flows on modern law, and, second, by the necessity to elaborate the integral concept of legal culture in the information society. The research objective is to analyze the legal effects of migration on legal culture of European countries and to distinguish new features of legal culture that have appeared in the digital era. Research methods: The main approaches to investigation into the problem were the analysis, modeling and comparative linguistics, as well as the content analysis of the key scientific theories on legislation. To study the topic, the authors applied comparative and structural-logical approaches that allow considering the law in terms of the influence of virtual environment, where the set of new component parts is observed. Results of the research: the paper traces the process of formation of new characteristics of component parts of legal culture in the society in the age of digital economy. The authors conclude that despite a number of contradictions observed in the process of law development in European countries, new features have appeared in law and legal culture of modern Europe in the context of digital economy. According to the authors, these features are the following: the increased influence of religious views on emotional-and-figurative and logical-and-statutory aspects of legal awareness; development of antagonistic relations between native Europeans and people belonging to different religious denominations; strong discontent of those natives who want to preserve their identity, which surely affects their legal behavior. The number of administrative offences and crimes has significantly increased. All these factors negatively affect the state of legal culture of the society. The paper analyzes the key problems related to implementation of the principle of the religious right provided to refugees, and some common violations of religious and legal regulations. Practical importance: The proceedings provided in this paper may be relevant when fulfilling scientific and educational tasks on legal theory and constitutional law.
\end{abstract}

\footnotetext{
*Corresponding author: pevtsova@bk.ru
} 


\section{Introduction}

The current millennium's leading trend is surely the digitalization, which is the result of the fourth industrial revolution. Professor Klaus Schwab fairly called its outcomes the "miracles of the $21^{\text {st }}$ century." Indeed, the world has entered the fantastic era of the new Planet, when people's identity is changing, humanity is being robotized, individual legal awareness is advancing, and legal awareness of the whole society as well [1, 2, 3].

According to the descriptive approach, the traditional law theory distinguishes legal ideology and legal psychology in the scope of legal awareness. The first component is defined through the level of legal knowledge and public awareness of law. The second one focuses on people's attitude to law: on either respect or rejection of its values. The latter would lead to legal nihilism and oblivion of the law itself. The constructive approach, which was proposed by some authors belonging to Russian legal science (E.A. Pevtsova, N.Y. Sokolov and others) [3, 4] classifies legal awareness into interconnected blocks: logical-normative, emotionally-figurative and motivational. The study of these blocks via digital technologies, particularly via social networks, allows analyzing the specifics of the current level of legal awareness of the society. This approach seems the most effective in a digital society, because it allows quantitatively and qualitatively determining the necessary indicators of each block in the legal awareness.

The increasing intercommunication between people via social networks allowed dividing the world into the real and virtual ones, which affected the state of legal awareness and legal culture of the society. The results of the industrial revolution (including the increased level of terrorism, online fraud, manipulation of people through social networks) were considered cruel and negative by many European, American and Chinese scientists (Xu Ming, Jeanne M. David and Suk Kim), which made it possible to come up with a new concept for transforming the world. To be more specific, the SPOD-world transformed into a new VUCA-world [3, 4]. The latter is characterized by such features as uncertainty, instability, impermanence, unpredictability and ambiguity. All these features surely affect legal awareness and legal culture of a society. However, in recent years, these factors have been complemented by consequences of the migration crisis that have manifested themselves in European countries. These consequences yet have not been fully represented in the scientific legal literature.

In today's Europe, there is a migration crisis associated with an increase in the number of refugees. This necessitates, first, a comprehensive study on ways to solve the problems of adapting external migrants to legal culture of the existing society and, second, the development of theoretical and new legislative approaches to protection of Europeans from possible infringement of their rights. Addressing this topic actualizes the problem of religious freedom of emigrants, with taking into account of the fact that all of them are adherents of different ideologies and beliefs. The study showed that values of refugees as of a social group may dramatically differ from those that predominate in their host countries. Therefore, there arises the problem of legal awareness and legal culture formation in such a society, while preserving religious identity of native inhabitants of Europe as a place of origin and spread of liberal and democratic doctrines. Thus, the relevance of the topic under investigation is explained by the existing contradiction between a plethora of popular research articles, empirical data on the impact of migration flows on European countries and the lack of fundamental scientific developments dedicated to its impact on legal culture and law of European countries. The second aspect that explains the topic's relevance is the need to work out specific recommendations to improve the legal culture of European countries at the same time preserving the eternal values that have been developed by native Europeans over the centuries. 


\section{Methods}

It seems that the problems above should be considered jointly, with the application of a comparative method and formal-legal analysis involving the use of empirical data (the present paper focuses mainly on Germany), statistics and the analysis of the regulatory enforcement practice of the European Court of Human Rights. During the study on the topic, results of the monitoring performed by statistics services of the European Union were used.

The investigation into the results of monitoring performed by the statistical service of the European Union reveals a steady increase in the number of refugees, which has been growing with a geometric progression for the recent years: in 2013 there were 431 thousand refugees, in 2015 - approximately 1,300,000 people, in summer 2019 all media headlines reported that "the whole mankind's history record was broken by the number of 71 million migrants." [5,6,7]. The beginning of 2020 was marked by several new global conflicts. Illegal migration, smuggling and arms trafficking have increased in many countries of the world. This situation was exacerbated by the confrontation between the national army and the Government of National Accord of Libya. Migration processes started affecting the legal culture of Europe even more significantly. No wonder that Angela Merkel's arrival in Moscow in January 2020 was associated with the discussion related to these issues. This situation is caused by numerous factors: economic, political, religious. It is difficult to single out exclusively dominant ones among them, because they are intertwined in the real world.

When moving to other countries, migrants find themselves in a relatively isolated community, which being already completed demands the effective international law incorporation. According to data from public opinion monitoring, which has been conducted since the 1970s as a part of the European Commission's study called Eurobarometer, Europeans of conservative views oppose migrants being granted citizenship and a full range of rights and are totally against people coming from other countries [8]. These findings have been repeatedly confirmed by sociological studies conducted in certain European countries and social surveys arranged via social networks. A single country is to be given as an example. In 2019, according to official data from the German Federal Statistical Office, mast of migrants in the country are of Turkish origin and follow Islam. Therefore, conservative respondents showed an extremely negative attitude towards migrants in general and to Muslims in particular. [9].

During investigation into the topic, some interviewing techniques were used. When staying in Germany and talking to the citizens, it becomes clear that they share widely different opinions on refugees. Some respondents beware migrants, they started being afraid to send their children to school without escort, because many refugees do not inspire confidence and seem dangerous. Some respondents feel very negatively about the behavior of foreigners, particularly in public transport or other crowded places, noting their disrespect for legal regulations and moral traditions. At the same time, there are Germans who believe that refugees should be supported. Native Germans feel empathy for those who suffer and feel pain, for children from countries where war goes on and people get shot and killed. At the same time, Germans are terribly shocked by a scene when refugees dressed in rags are sitting in the streets of European countries lacking food, money and not even knowing the language. According to the survey data, there are a lot of people in Germany who sheltered refugees and helped them having provided clothes, food, money and accommodation $[9,10]$.

In addition, Germany has a strongly pronounced demographic problem. The country lacks young professionals, which hampers the generation of a tax component in country's budget for social programs including pensions and compensations. According to 
calculations made, if the country's birth rate does not grow and young people do not reinforce the country's population, Germany will have 7 pensioners for one worker $[11,12]$. This situation makes the government increase taxes.

No wonder that the issues of migrant integration into the labor sector have become topical in the discussion at the governmental level. The result of the agreements reached in resolving such issues was the creation of an organization Wir zusammen ("We Together"). In 2019, it included 36 companies, 19 of which are large concerns and holdings. For instance, the state-owned company Deutche Bahn (Railway) has 200 open positions out of total 200 thousand ones for refugees [13-18].

The study involved a legal analysis of regulatory acts governing the behavior and status of refugees. According to the EU Directive on granting refugee status [19], this status is assigned to people arrived in the European Union from least developed countries, if they are racially, nationally, politically or religiously persecuted, as well as are victimized because of their belonging to a particular social group. The term "persecution" refers to acts that constitute gross violations of fundamental human rights.

Since 1999, there have been Guidelines on Fair and Efficient Procedures for Determining Refugee Status [20]. This document stipulates that the law ensures granting of appropriate status to those who need protection. This refers not only to simple asylum seekers, who are defined in the 1951 Refugee Convention [21-23] and in the corresponding 1967 Protocol, but also to those asylum seekers who need international protection yet are not covered by the direct interpretation of the provisions of the 1951 Convention. This may apply to cases provided for in Art. 3 of the European Convention for the Protection of Human Rights and Fundamental Freedoms, Art. 3 of the UN Convention against Torture and Art. 7 of the International Covenant on Civil and Political Rights or more broadly defined complementary forms of protection. Legal regulation of the problem is executed by a number of local laws of European countries. For example, in Germany, refugees are accepted and provided with political asylum under regulation performed by Asylgesetz [24, 25]. (German special law governing asylum for refugees). This law defines the procedures for submitting documents, agencies and bodies accountable for document processing, processes of consideration and decision-making on assigning the status. Similar laws exist in other countries as well. Therefore, when conducting a study, one should take into account not only international law, but also specifics of each particular country's national law.

\section{Results}

What are the effects of the migration flow to European countries on legal culture of the society in the context of digitalization?

The indicator of legal awareness of the society has sharply decreased in the structure of legal culture; a relatively new component has appeared that takes into account religious views of a person (we will call it the religious-worldview component); the emotionalfigurative aspect has changed, which manifests itself in the increase in a number of cases of disrespect for the law and legal values of the established European society. This allows reconsider the law as a set of rules that places a high value on spiritual, moral, religious and worldview values defined by the existing society and related to the state, because it is the state that has to take measures to reduce social tension, balancing between protecting the rights of natives and supporting refugees arrived from eastern countries. Religious trends as a part of the religious-worldview component are very contradictory, heterogeneous and give rise to numerous conflicts in the relationships between those who share certain views.

As a result of the study, the authors found out that legal culture of European countries experiences the development of new characteristics that influence the state of the elemental 
composition of this legal structure. In particular, migration flows entailed the influence of religious beliefs not only on the logical-and-statutory block (the level of legal awareness), but also on the emotional-and-figurative block of legal awareness (attitude to the law and legal institutions of society). The values and behavioral rules widely accepted by locals started undergoing certain transformation. Meanwhile, the culture of refugees besides being not incorporated into the existing legal space, opposes itself to traditions and foundations of the society. This fact causes discontent among local residents and exacerbates social tensions in European countries. The number of offenses related to violation of local laws has increased. The number of offenses committed on religious grounds has risen sharply. For example, there were observed several new conflicts of different Muslim organizations with each other and with local people on confessional issues. A good example is the statements on wearing a niqab (a garment of clothing that covers the face) by women, that were made by the leaders of Fadela Amara's movement. At the same time, refugees seem to have a desire to assimilate and even are ready to switch their religious beliefs to the rules accepted among the local people. [26, 27]. However, legal norms established for refugees do not always allow them to freely exercise their right to religious beliefs.

\section{Discussions}

Theory and practice assess the impact of migration processes on legal culture ambiguously. Some data provoking discussion is presented below.

In 2012, the European Court of Human Rights indicated that EU countries are obliged to provide asylum to those foreigners who are persecuted for public manifestations of their religious affiliation, if these persecutions are found sufficiently serious. [28,29,30]. The court considered the case upon the request from Germany. Two refugees from Pakistan acquired the victim status. They were the members of the Ahmadiyya Muslim community (representing one of the Islamic movements). It is known that the majority of Pakistan's population are the Sunni Muslims, while members of another Islamic branch, the Ahmadis, are forbidden to consider themselves Muslims and worship freely (sanction for violation is imprisonment for up to three years). The situation was escalated by the following facts: as it is known, Ahmad is the middle name of the prophet Muhammad, and according to religious doctrine, any sacrilegious statements about him are punished by life imprisonment or death penalty. Nevertheless, Mirza Ghulam Ahmad, the founder of the Ahmadiyya Muslim community, declared that he was a reincarnation of the prophet $[31,32]$.

In Germany, courts of different levels passed directly opposite judgments on the case described above, therefore it was necessary to apply to the ECHR, which in its resolution emphasized that freedom of religion implies the right to manifest one's religious affiliation and worship publicly. In addition, the European Court of Human Rights indicated that the key factor when deciding on granting a refugee status is the severity of persecution and the severity of punishments that expect a believer. Muhammad Dawood Majoka, a representative of the Ahmadiyya Muslim community in Germany, points out that although no death sentence against Ahmadites has yet been executed in Pakistan, many of his coreligionists sentenced to death are now in condemned cells waiting for a decision on their fate. This case is of interest because when considering it, the Court elaborated and formulated certain criteria for finding a case of prosecution "sufficiently serious". Thus, this decision largely protected the rights of persons seeking asylum in the EU for religious reasons $[33,34]$.

As for constitutional provisions of the states, which have to deal with the largest flows of emigrants, it is observed that in most constitutions the model of a secular state is enshrined (Germany, France, Belgium). In some constitutions, the freedom of religion is enshrined yet with a special role of the Catholic Church (Spain, Italy, Andorra), Eastern 
Orthodox Church (Bulgaria, Greece) or Lutheran Church (Sweden, Finland). This fact suggests that technically the secular Europe, at least its major part, should not be against migrants who left their countries because of religious issues, but reality is not that. [35].

Further legal regulations are addressed in order to have data to compare with. In the first paragraph of section 3, Asylgesetz defines the scope of people who can acquire refugee status: "A foreigner is considered a refugee if they are outside the territory of their state due to reasonable fears of persecution based on racial, religious, national grounds, political views or belonging to a particular social group, and they do not have the opportunity to be protected in their own state or do not want to be protected because of persecution."

According to statistics from the Bundesamt für Migration und Flüchtlinge (BAMF German Federal Office for Migration and Refugees), 33\% of approximately seventy thousand requests for the first half of 2014 were refused, $39.7 \%$ of cases were closed on formal grounds without even considering. $18.7 \%$ of people acquired the refugee status and $1.5 \%$ got the political asylum. Approximately $7 \%$ did not acquire any status, but were taken under various types of social protection and were not sent back to their countries. These statistics indicate that 4 out of 5 people did not receive political asylum, and their rights were not protected. If recalling the exponential increase in the number of refugees in the world and assuming that the number of refusals in granting political asylum or refugee status will decrease in the future, it can be concluded that Europe can be simply "teared up" by the influx of emigrants. [32,36].

According to German practice, to apply for refugee status, a person can address any official authority either in oral or in writing form (for example, through the police station). After addressing, the authorities will send the applicant further to the Bundesamt für Migration und Flüchtlinge (BAMF) - the Federal Office for Migration and Refugees.

At the first stage, all asylum seekers are sent to camps. Germany has about twenty camps of that kind. Such a camp is a territory enclosed with fence, where there are bunkhouses, doctors, a canteen (as many refugees say on social networks, food there is represented mainly by porridges or mashed potatoes in bags). It is hard to know in advance who will get to which camp, because it depends on the availability of vacant places. Everyone who has applied to the BAMF is obliged to live in the camp, regardless of whether they want it or not $[33,34]$.

There are representatives of various religious faiths in such refugee camps, and even there the same conflicts may arise as those which made people escape from their homelands.

A perfect example of such a statement is an open letter of the Viceroy of the Berlin Orthodox Monastery of St. George (Moscow Patriarchate), Hegumen Daniel to the Federal Minister for Special Assignments, Peter Altmaier, which says how Christians and Yezidis from Syria and other countries of the Middle East and North Africa are severely harassed by their Muslim neighbors. [36]. The letter states the following: "Christian refugees from Syria and a number of other countries are being bullied, they are severely oppressed by their Muslim neighbors." In addition, there is a growing number of cases, when persecution results into injuries and death threats, bringing physical suffering to refugees and their families.

Former Muslims who converted to Christianity have to endure severe bullying. According to the worldview of radical Muslims, "apostates" should be afraid for their lives, because from the moment they abandon Islam, they lose their right to live. Refugees are afraid of being beaten or killed asleep at night, so they have to spend nights outside the camps: for example, in the Evangelical Lutheran Church of the Holy Trinity in the Steglitz district of Berlin.

Many migrants from the Middle East suffer from oppression so much that they want to go back home, because even a place, where there is war and horror, terrifies them less than 
those severe religious harassments experienced by them in refugee camps in Germany. At the same time, police rarely become involved in interreligious conflicts.

A lot of people often mention that Muslims show hatred towards representatives of other faiths. For example, Josef Schuster, the chairman of the Council of Jews in Germany, at the meeting with German Chancellor Angela Merkel, emphasized that the endless influx of refugees coming from eastern states, without any control or restrictions executed by those states, where Islam is besides being a prevailing religion, is also enshrined in law as the state religion, leads to the fact that immigrants with anti-Semitic views inspire fear in citizens of Germany. [36].

Many refugees are resettled because of terrorist attacks made by ISIS (organization banned in Russia - note by N. Pevtsova). They just like Europeans are overwhelmed with a desire to live in peace, freedom and harmony, which is greeted by Germany. However, their culture and education cultivate hatred towards Jews, disrespect for women and violent opposition to sex minorities. This is not only an ethnic problem. This problem is mainly related to freedom of religion, which is evidenced by incidents taking place in European countries with a large share of Muslim population. [37].

German newspaper Welt am Sonntag published information that the Federal Office for the Protection of the Constitution (BfV, internal counterintelligence) and the Federal Intelligence Service (BND, external intelligence) are concerned about the influx of Muslim refugees who hate Jews, that sweeps through Germany and leads to civil disturbances. That article says that the import of Arab anti-Semitism, Islamic extremism, national and ethnic conflicts leads to dissonance in the society and undermines the security of the state. According to sources of special services, the integration of about 100,000 illegal migrants into German society is no longer possible due to the existence of a number of "parallel communities" in the country. [38]. German intelligence agencies cannot cope with security issues for the favor of the ruling parties.

Russia has been also affected by the refugee problem. One case should serve as an example showing that all these global problems are not that simple, and the coin named "migration" has two sides. In November 2019, the ECHR pronounced judgement which obliged Russia to pay 80 thousand euros to migrants having asked for political asylum in the transit zone of Sheremetyevo International Airport. [39,40]. Citizens of Iraq, Somalia, Syria and the partially recognized state of Palestine applied in 2015 for getting refugee status in Russia. However, the border authorities denied them entry into the Russian Federation. The Office of the United Nations High Commissioner for Refugees (UNHCR) helped Iraqi and Syrian citizens move to Denmark and Sweden in March 2016, the person from Palestine moved to Egypt in February 2016, while the citizen of Somali stayed in Sheremetyevo until March 2017. Perhaps at first glance the situation seems terrible: Russia supposedly kept people in a noisy airport without providing any accommodation or shower for almost two years. However, as Representative of the Russian Federation at the European Court of Human Rights Mikhail Galperin notes, it is necessary to make clear distinctions between refugees fleeing war and persecution and those who left their states to find better life and get the financial support for refugees in Europe. This opinion was supported by the Hungarian authorities, who joined the trial as an independent participant on the side of Russia. The Russian Ministry of Justice also stated that such a long stay of foreigners at the airport was not a deprivation of their freedom, it was the "free and deliberate choice" that those people made on their own. [41]. However, the resolution was revised, and in 2019 the Grand Chamber pronounced a unanimous judgement. Then Dmitry Dedov, the judge of the ECHR from the Russian Federation, who had previously voted against finding violations of the Convention, also sided with the applicants. Nevertheless, this case highlights the following problems: difficulties in ensuring the country's security, necessity to provide support to people from other states (in obtaining relevant documents, 
necessary control procedures), real oppression of refugees in countries, perticularly on religious grounds [42].

\section{Conclusion}

The study showed that migration flows have had been affecting the state of European countries' legal culture. The legal culture of the European community has religious components becoming more visible. Although the term "religion" has not yet been defined in international law, freedom of religion is constitutionally considered the value in many European states. Most European countries are secular states, but refugee flows have made a fresh input to the development of legal culture and emphasized the need to incorporate religious beliefs into real legal practice. As a result, there arose a need to develop a new concept of legal culture of European countries in the digital era. This concept can be described as follows. In the age of Big Data and digital economy, the law of European countries acquires virtual features, yet the institutionalization of virtual law cannot be stated, because the law represents the rules of conduct that relate to a state and do not exist outside the physical world, but are formally registered in current law sources of the state. Therefore, the combination of the words "virtuality" and "law" should not be taken literally. The law itself is not virtual, it is real in the legal space, even within the virtual world. Legal culture in the digital age can be manifested through the combination of legal awareness (logical-and-regulatory block of legal awareness of the society), attitude to law (emotional-figurative block of legal awareness of the society) and the legitimate behavior of the population, which is determined through specific actions of people in both real and virtual worlds. Moreover, in the structure of legal culture, the religious-worldview component that affects the behavior of people as private persons and their communities should be taken into account.

\section{References}

1. S.S. Sulakshin, V.E. Bagdasaryan, Bylyye gody. Rossiyskiy istoricheskiy zhurnal 34(4), 72 (2014)

2. N.A. Barinova, Ye.V. Karunas, Kazanskiy pedagogicheskiy zhurnal 3(110), 70-75 (2015)

3. Y. Kotsar, D. Bevza, Pol-Zemli v oflayne, https://www.gazeta.ru/tech/2014/11/25_a_6314337.shtml

4. E. Davidov, B. Meuleman, J. Billiet, P. Schmidt, European Sociological Review 24(5), 583-599 (2008)

5. Y.V. Paukova, Migratsionnoye pravo 1, 18 - 21 (2019)

6. V.B. Pervozvanskiy, Y.N. Strogovich, Ugolovno-ispolnitel'naya sistema: pravo, ekonomika, upravleniye 4, 13 - 16 (2019)

7. C. Beierlein, F. Kuntz, E. Davidov, Social Science Research 58, 68-79 (2016)

8. Cyberpunk Manifesto by Christian As. Kirtchev, http://project.cyberpunk.ru/idb/cyberpunk_manifesto.html

9. V. Lurie, Chto izmenitsya c prinyatiyem zakona ob avtonomnom internete? https://orpravo.org/news/zakon-internet/

10. Ye.N. Markova, Zhurnal Konstitutsionnoye i munitsipal'noye pravo 11, 34-45 (2018)

11. UK to introduce world first online safety laws, https://www.gov.uk/government/news/uk-to-introduce-world-first-online-safety-laws 
12. United Nations Convention on the Use of Electronic Communications in International Contracts, https://www.uncitral.org/pdf/english/texts/electcom/06-57452_Ebook.pdf

13. V.S. Katz, C. Gonzalez, K. Clark, Digital Inequality and Developmental Trajectories of Low-income, Immigrant, and Minority Children, https://pediatrics.aappublications.org/content/140/Supplement_2/S132

14. World summit on information society concludes first phase by adopting declaration of principles and plan of action PI/1550 https://www.un.org/press/en/2003/pi1550.doc.htm

15. https://www.wir-zusammen.de/das-netzwerk/ueber-uns/

16. https://www.refworld.org/cgibin/texis/vtx/rwmain/opendocpdf.pdf?reldoc=y\&docid=47272e $2 \mathrm{f} 2$

17. https://www.un.org/ru/documents/decl_conv/conventions/refugees.shtml

18. https://www.echr.coe.int/Documents/Convention_RUS.pdf

19. https://www.un.org/ru/documents/decl_conv/conventions/pactpol.shtml

20. https://www.gesetze-im-internet.de/asylvfg_1992/

21. Directive N 2011/95/EU of the European Parliament and of the Council on standards for the qualification of third-country nationals or stateless persons as beneficiaries of international protection, for a uniform status for refugees or for persons eligible for subsidiary protection, and for the content of the protection granted

22. https://www.un.org/ru/documents/decl_conv/conventions/refugees.shtml

23. https://www.echr.coe.int/Documents/Convention_RUS.pdf

24. https://www.un.org/ru/documents/decl_conv/conventions/pactpol.shtml

25. Digital divide, https://www.techopedia.com/definition/605/digital-divide

26. E. Hargittai, Weaving the Western Web: Explaining differences in Internet connectivity among OECD countries, http://www.webuse.org/pdf/HargittaiSurveyMeasures2005.pdf

27. E. Hapks, Regulation, Self-regulation or Co-regulation, https://www.researchgate.net/publication/322266821_Regulation_Selfregulation_or_Co-regulation

28. Finding Online Volunteering. Virtual Volunteering. Online Micro volunteering \& Home-Based Volunteering, https://www.coyotecommunications.com/stuff/findvv.shtml

29. Helen Roberts. Can the Internet be regulated? https://www.aph.gov.au/About_Parliament/Parliamentary_Departments/Parliamentary Library/pubs/rp/RP9596/96rp35

30. How to regulate internet: new paradigms forinternet governanceself - regulation: value and limits, http://www.crid.be/pdf/public/4656.pdf

31. Federalist Society Review 18, https://fedsoc.org/commentary/publications/how-toregulate-the-internet

32. https://www.rbc.ru/rbcfreenews/5bdaf5329a79475d77c8a003

33. Internet Self-Regulation: An Overview, http://www.law.unisofia.bg/Kat/T/IP/T/PM/DocLib/Internet\%20SelfRegulation\%20An\%20Overview.htm

34. J.P. Barlow, A Declaration of the Independence of Cyberspace, https://www.eff.org/cyberspace-independence 
35. K. Schwab, The Fourth Industrial Revolution, https://luminariaz.files.wordpress.com/2017/11/the-fourth-industrial-revolution-201621.pdf

36. Legalguide

on

electronic

fundstransfers, https://www.uncitral.org/pdf/english/texts/payments/transfers/LG_E-fundstransfere.pdf

37. Okinawa

Charter

on

Global

Information

Society, https://www.mofa.go.jp/policy/economy/summit/2000/documents/charter.html

38. P. DiMaggio, E. Hargittai, From the 'Digital Divide' to 'Digital Inequality: Studying Internet Use as Penetration Increases, https://ideas.repec.org/p/pri/cpanda/workpap15.html.html

39. P.A. Pierlot, Self-Regulation of Internet Content: A Canadian Perspective, https://web.archive.org/web/20160103042124/http://www.isoc.org/inet2000/cdproceed ings/8k/8k_2.htm

40. Peng Hwa Ang, How Countries Are Regulating Internet Content, https://web.archive.org/web/20160103124414/https://www.isoc.org/inet97/proceedings /B1/B1_3.HTM

41. Recommendation on the Legal Value of Computer Records https://www.uncitral.org/pdf/english/texts/electcom/computerrecords-e.pdf

42. H. Rheingold, The virtual community: Homesteading on the electronic frontier (New York, HarperCollins, 1994) 